\title{
Correction to: Ultrathin gold nanowires to enhance radiation therapy
}

Lin Bai ${ }^{1,2 \dagger}$, Fang chao Jiang ${ }^{3 \dagger}$, Renjie Wang ${ }^{1,2+}$, Chaebin Lee ${ }^{3}$, Hui Wang ${ }^{4}$, Weizhong Zhang ${ }^{3}$, Wen Jiang ${ }^{3}$,

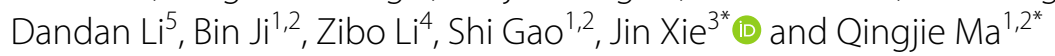

\section{Correction to: J Nanobiotechnol (2020) 18:131} https://doi.org/10.1186/s12951-020-00678-3

Following publication of the original article [1], the authors identified an error in Fig. 5c.
The correct Fig. 5c and its caption is given in this erratum.

The original article has been revised.

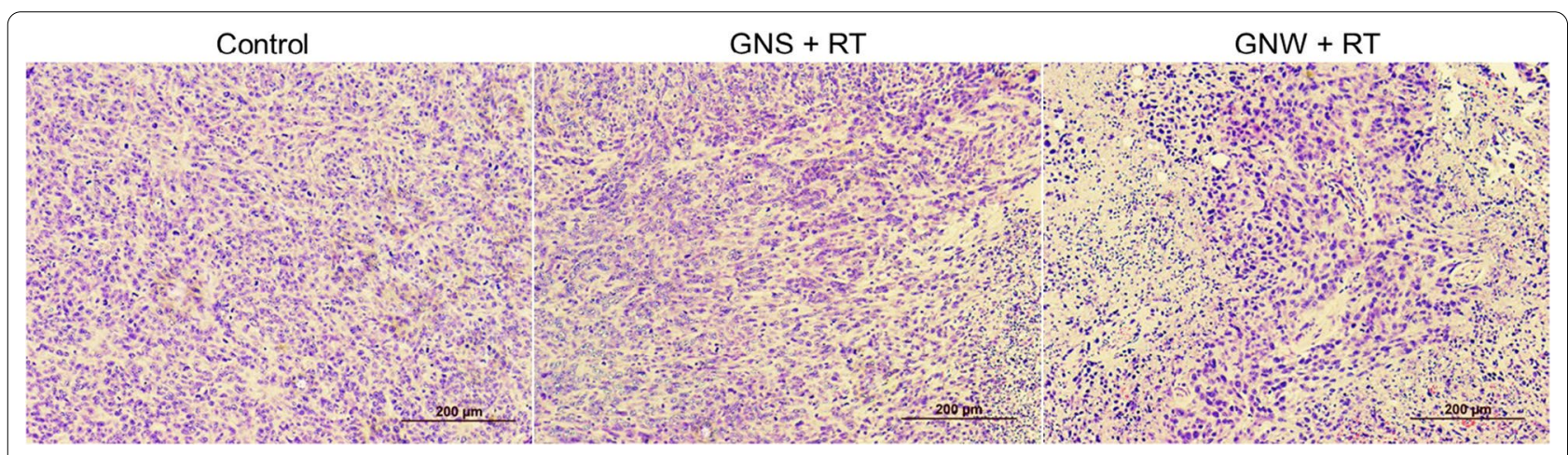

Fig. 5 c H\&E staining of tumor tissues taken from treated animals. Scale bars, $200 \mu \mathrm{m}$

The original article can be found online at https://doi.org/10.1186/s12951020-00678-3.

\footnotetext{
*Correspondence: jinxie@uga.edu; maqj@jlu.edu.cm

${ }^{\dagger}$ Lin Bai, Fangchao Jiang and Renjie Wang contributed equally to this work

1 Department of Nuclear Medicine, China-Japan Union Hospital of Jilin University, Changchun 130033, Jilin, China

${ }^{3}$ Department of Chemistry, University of Georgia, Athens, GA 30602, USA

Full list of author information is available at the end of the article
}

\section{BMC}

(c) The Author(s) 2021. This article is licensed under a Creative Commons Attribution 4.0 International License, which permits use, sharing, adaptation, distribution and reproduction in any medium or format, as long as you give appropriate credit to the original author(s) and the source, provide a link to the Creative Commons licence, and indicate if changes were made. The images or other third party material in this article are included in the article's Creative Commons licence, unless indicated otherwise in a credit line to the material. If material is not included in the article's Creative Commons licence and your intended use is not permitted by statutory regulation or exceeds the permitted use, you will need to obtain permission directly from the copyright holder. To view a copy of this licence, visit http://creativecommons.org/licenses/by/4.0/. The Creative Commons Public Domain Dedication waiver (http://creativecommons.org/publicdomain/zero/1.0/) applies to the data made available in this article, unless otherwise stated in a credit line to the data. 


\section{Author details}

Department of Nuclear Medicine, China-Japan Union Hospital of Jilin Univer-

sity, Changchun 130033, Jilin, China. ${ }^{2} \mathrm{NHC}$ Key Laboratory of Radiobiology,

School of Public Health of Jilin University, Changchun 130033, Jilin, China.

${ }^{3}$ Department of Chemistry, University of Georgia, Athens, GA 30602, USA.

${ }^{4}$ Department of Radiology, University of North Carolina at Chapel Hill, Chapel Hill, NC 27599, USA. ${ }^{5}$ Department of Gastrointestinal Medicine, Endoscopy Center, China-Japan Union Hospital of Jilin University, Changchun 130033, Jilin, China.

\section{Reference}

1. Bai L, Jiang F, Wang R, Lee C, Wang H, Zhang W, Jiang W, Li D, Ji B, Li Z, Gao S, Xie J, Ma Q. Ultrathin gold nanowires to enhance radiation therapy. J Nanobiotechnol. 2020;18:131. https://doi.org/10.1186/ s12951-020-00678-3.

\section{Publisher's Note}

Springer Nature remains neutral with regard to jurisdictional claims in published maps and institutional affiliations.

Published online: 19 July 2021 